\title{
荌 THE SECOND MISSION OF THE SERBIAN ARMED FORCES - GENESIS, CHARACTERISTICS AND MEDIA TREATMENT
}

Mileva Zotović

Ministry of Defence of Republic of Serbia

tarting from the belief that security risks in the modern world confirm

indivisibility of security at a global level that is a very high level of interdependence between states and regions, the Republic of Serbia, acting on its foreign policy plan, advocates affirmation of cooperative security concept. ${ }^{1}$ In accordance with this, it takes an active part in the process of cooperation with other states within international organizations in order to strengthen security and peacekeeping in the world. The Republic of Serbia gives a concrete contribution to keeping international peace and stability by participation of the Serbian Armed Forces members in UN multinational operations, which has expanded during the last years. Furthermore, bearing in mind the fact that the EU membership is one of the priorities of its foreign policy, the Republic of Serbia (although it has the status of a candidate for admission, and not a full member) also participates in EU multinational operations in accordance with its capacities.

The first part of this paper presents the historical review of participation of the Armed Forces of our country in UN traditional peacekeeping missions, as well as the review of the undertaken activities (after renewal of participation in 2002) in order to create preconditions for greater stepping of the Serbian Armed Forces on international scene. The second part shows results of the research during which there were attempts to come to knowledge about relation of media to participation of the Serbian Armed Forces members in UN and EU multinational operations by analysis of media content.

Key Words: SAF missions, UN and EU multinational operations, media reporting

\section{Introduction}

The effect of foreign policy of each state including the Republic of Serbia on national security cannot be questioned and it is multidimensional. Moreover, national security of the state depends largely on the success of foreign policy decision-makers in

\footnotetext{
${ }^{1}$ See more on cooperative security concept in Dragan Simić, Nauka o bezbednosti - savremeni pristupi bezbednosti, the Official Gazette of the Federal Republic of Yugoslavia and the Faculty of Political Sciences, Belgrade, 2002, p. 83-101.
} 
assessing the current situation and potential direction of development of relations in the international community, then on the choice of objectives, means for their achievement and concrete activities that are undertaken. "It cannot be denied that foreign policy affects predominantly security of some state. Wise, controlled and pragmatic foreign policy affects inevitably the state of its total security."2 With respect to the fact that many authors define differently the relation of foreign policy and national security, it can be still concluded that in professional public there is a high degree of agreement that foreign policy of each state has a very great influence on its security. The example of the Republic of Serbia is surely not an exception. Indeed, it confirms the abovementioned statement.

Considering the fact that foreign policy is a very important element of security policy, in its foreign policy the Republic of Serbia starts from the belief that development of cooperation at a bilateral and multilateral level can significantly contribute to national security in terms of the reduction of a danger of a state being threatened. In this context, it advocates strengthening of the role of the UN as a universal organization, getting the status of the EU member and active participation in the NATO programme "Partnership for Peace" (in those activities that are planned for the states, which do not have the status of the North Atlantic Alliance member), taking into account the opinion on neutrality of the state in relation to the existing military alliances.

Following the tradition of participation in UN peacekeeping operations, the Republic of Serbia gives a concrete and significant contribution to the efforts to keep the peace in the world. According to its scope of participation in UN and EU multinational operations, which has expanded in recent years, ${ }^{3}$ the Republic of Serbia is among the first ten European countries, and among the Western Balkans countries it is in a leading position. Currently, the Serbian Armed Forces members take part in six UN peacekeeping missions: MONUSCO (DR Congo), UNMIL (Liberia), UNFICYP (Cyprus), UNIFIL (Lebanon), UNTSO (Middle East), MINUSCA (Central African Republic) and four EU operations: EUTM Somalia, EUTM Mali, EUTM RCA and EUNAVFOR Operation Atalanta. ${ }^{4}$ At this moment, 344 Serbian Armed Forces members are engaged. At the same time, the Republic of Serbia in on the $49^{\text {th }}$ place among contributors out of 127 countries participating in multinational operations. As a sign of certain recognition for contribution that it gives to the UN efforts, three certified UN courses are conducted in the Peacekeeping Operations Centre, which is a great acknowledgement, having in mind that only two centres in the world have such thing. ${ }^{5}$ Besides that, the first regional conference about participation of the Western Balkans countries in UN peacekeeping missions was held in October 2014 in Belgrade.

\footnotetext{
${ }^{2}$ Mitar Kovač, „Politička ili vojna neutralnost Republike Srbije”, Ekonomija i bezbednost, CIMIC Centre, Belgrade, 2009, p. 152.

${ }^{3}$ See Graph 1.

${ }^{4}$ www.mod.gov.rs, www.vs.rs

${ }^{5}$ According to the data of the Peacekeeping Operations Centre announced at the Regional Conference "Media, multinational operations and migrant crisis" held in Kovačica at the beginning of December 2017.
} 


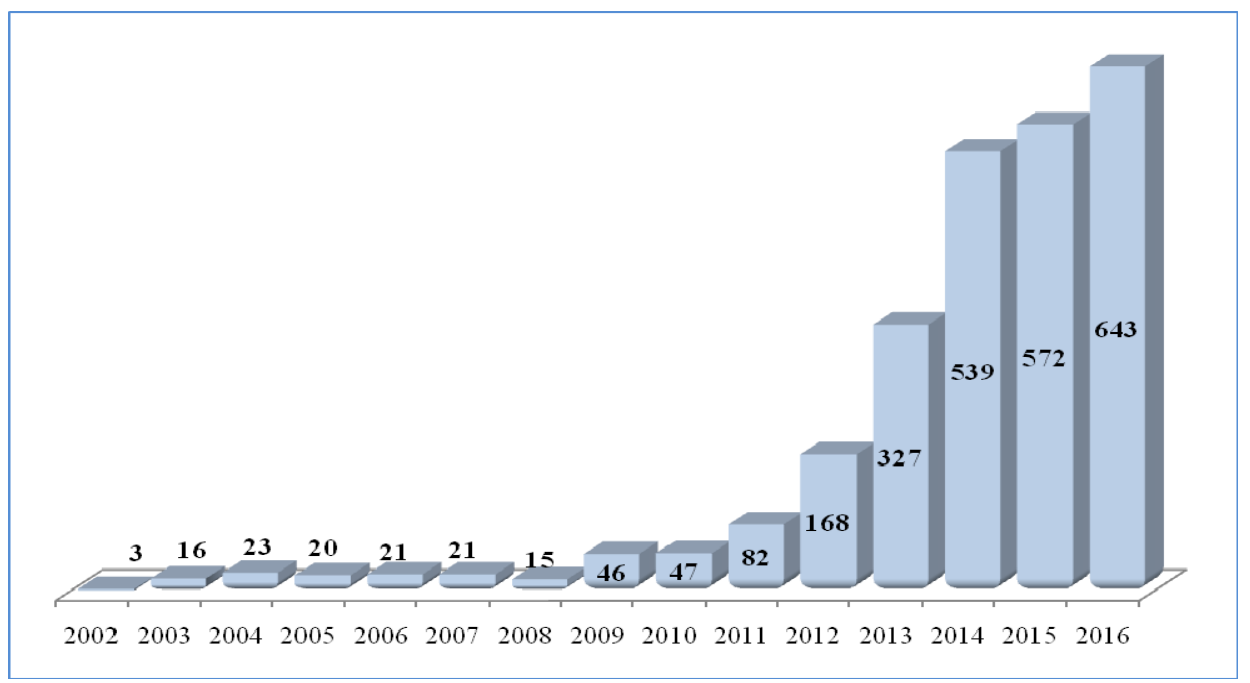

Graph 1 - Number of SAF members engaged in UN and EU multinational operations (from 2002 until 2016)

\section{Continuation of rich tradition}

The Socialist Federal Republic of Yugoslavia as one of the UN founders, was rather noticeable among members of the world organization by its participation in "traditional“ peacekeeping operations. Yugoslavia gave a significant contribution to peacekeeping in the world by affirming the principle of peaceful active coexistence as one of the founders of the Non-Aligned Movement.

Furthermore, the state leadership at that time thought that this orientation affected the raising of the country's reputation in the international community. Therefore, 11-yearlong engagement of the Yugoslav National Army members in Sinai from 1956 until 1967 under the auspices of UNEF-1 peacekeeping mission resulted in participation of over 15.000 members of the Yugoslav Army. The engagement in UN peacekeeping missions in the following period (in Congo, Yemen, Iraq-Iran, Namibia and Angola) was not so massive. However, it was assessed as very successful, which is illustrated by the UN medals from that period.

During the wars in the territory of former Yugoslavia, Serbia was subjected to sanctions for many years within the Federal Republic of Yugoslavia and it was practically in international isolation. In such circumstances, in the territory of former Yugoslavia the international community initiated peacekeeping operations, which differed very much, according to their characteristics, from traditional ones (conducted so far). Moreover, in the period after the Cold War, the nature of conflicts in the world has largely changed (the focus of conflicts has been transferred from interstate to a level of intrastate conflicts), and the way of their resolution, as well. 
After the break lasting for several decades, from 2002 Yugoslavia has renewed its engagement in UN peacekeeping operations (mainly by sending military observers). Preparations for their engagement were full of numerous problems (status, equipping, etc.), which were mainly caused by the lack of legal regulation. Certain steps were made by establishment of the Peacekeeping Operations Centre (2003) and passing certain legal acts (2004). However, it was not enough for more active participation in peacekeeping operations.

Only by passing the set of defence laws in 2009, preconditions were created for a stronger step forward in terms of the Serbian Armed Forces members participation in UN peacekeeping operations. Besides passing the National Security Strategy and the Defence Strategy of the Republic of Serbia, as well as amendments to the Law on Defence and the Law on the Serbian Armed Forces, enacting the Law on engagement of the Serbian Armed Forces and other defence forces in multinational operations outside the Republic of Serbia borders is particularly important. Moreover, its provisions regulate very precisely types of peacekeeping operations in which the Serbian Armed Forces members can participate, then the process of decision-making about their engagement, as well as their status, rights and obligations during participation in multinational operations.

Besides missions under the UN auspices, the members of the Ministry of Defence and Serbian Armed Forces have recently participated in EU multinational operations (training of Somali Forces, operation against pirates in Somalia, training of the armed and security forces in Mali and the Central African Republic). The basis for the engagement of the Serbian Armed Forces members in these operations is the fact that the EU membership is the priority foreign policy objective of the Republic of Serbia. Since the Republic of Serbia has the status of a candidate for admission, and not a full member, by signing adequate treaties preconditions have been created for the engagement of representatives of the Republic of Serbia in operations and missions under the EU auspices. Thus, Serbia expresses a commitment to give its contribution to the Common Foreign and Security Policy of the EU. ${ }^{6}$

\section{Normative-legal aspect}

Participation of the Serbian Armed Forces members in multinational operations is regulated in accordance with provisions of numerous documents, which constitute normative-legal framework of their engagement outside the Republic of Serbia borders.

"As the supreme legal act, the Constitution of the Republic of Serbia defines the position and competences of the Armed Forces, their use outside the borders of the country, as well as the fact that the Serbian Armed Forces are under democratic and civil control. According to the Constitution, the Serbian Armed Forces defend the country from external threats and they conduct other missions and tasks, in compliance with the Constitution, the law and principles of the international law that regulate force". ${ }^{7}$

\footnotetext{
${ }^{6}$ In this context, Serbia has joined the EU Battlegroup Helbroc.

${ }^{7}$ Vanja Rokvić: Položaj vojske u političkom sistemu Republike Srbije (see: Mladenović, Ivaniš, Rokvić, Razvoj institucija i izgradnja političkog sistema Srbije, Faculty of security studies, Belgrade, 2012, p.107).
} 
The second mission of the Serbian Armed Forces - genesis, characteristics and media treatment

The National Security Strategy of the Republic of Serbia represents the initial document, which determines the foundation of security policy in protection of national interests of the Republic of Serbia. This main strategic document that directs the engagement of defence resources and development of normative, doctrinal and organizational solutions of the Serbian defence system, defines the missions and tasks of the Serbian Armed Forces including participation in peacebuilding and peacekeeping in the region and world. The White Paper on Defence emphasizes the significance of participation of the members of the Ministry of Defence and Serbian Armed Forces in UN multinational operations, and also EU ones because the EU membership is the priority foreign policy objective of the Republic of Serbia.

The Law on engagement of the Serbian Armed Forces and other defence forces in multinational operations outside the Republic of Serbia borders, which was passed in 2009 , regulates in detail the issue of participation of the Republic of Serbia in multinational operations. The rights and obligations of competent authorities in relation to participation of the Serbian Armed Forces members in multinational operations are already mentioned in the main provisions of the abovementioned law. The decision-making process on participation of the members of the Ministry of Defence and Serbian Armed Forces in multinational operations is regulated in detail (from decision-making on engagement until potential withdrawal from a mission).

In compliance with legal provisions, the decision on engagement of the Serbian Armed Forces in multinational operations is made by the Government of the Republic of Serbia on the basis of the Annual plan of engagement of the Serbian Armed Forces in multinational operations that is prepared by the Ministry of Defence in accordance with defence regulations. The Annual plan of engagement stipulates: the name of planned missions that is multinational operations; their mandate; a review of missions that is multinational operations, whose conduct is ongoing with assessment of the situation; objective to be met by engagement of the Serbian Armed Forces and other defence forces in multinational operations that are planned in the current year; available forces and material and financial resources, which can be put at disposal for taking part in multinational operations, as well as other elements, which are significant for the approval of participation in those operations.

\section{System activities}

Besides normative-legal aspect that is regulated in detail, preconditions have also been created within the Serbian Armed Forces for a greater step forward in the field of engagement of their members in multinational operations.

The knowledge from the field of social sciences provided by curricula in the military schools is the adequate basis for understanding international relations, comprehending national interests of the Republic of Serbia, as well as realizing the need and importance of participation in UN and EU multinational operations.

The training system of the Serbian Armed Forces members has been modified and adapted to contemporary requirements, which are made in executing the second mission of the Serbian Armed Forces (participation in peacebuilding and peacekeeping in the 
region and world). Due to interoperability with other participants in multinational operations, the existing competences and skills (if there are potential variations) are improved if necessary by additional training in order to reach the level of full compliance.

Starting from the belief that a high level of foreign languages knowledge (mainly English) is necessary for successful execution of tasks in multinational operations at all levels (especially in mission headquarters), the Military Academy carries out continuously training of the members of the Ministry of Defence and Serbian Armed Forces within STANAG programme.

Only the Serbian Armed Forces members who have previously been adequately prepared and equipped with adequate equipment are sent to UN and EU multinational operations. The Peacekeeping Operations Centre issues the certificate for the training level of the Serbian Armed Forces members, who are candidates for participation in multinational operations. In addition to detailed preparations at a national level, preparations at international level (multinational) are carried out if necessary. In difference to the period after the continuation of participation in multinational operations (2002), when mainly individuals were engaged (military observers, staff officers, etc.), currently the Serbian Armed Forces company and platoon (in Lebanon and Cyprus) are engaged in multinational operations. Moreover, the interest for participation in multinational operations is very high. ${ }^{8}$

In compliance with guidelines from the National Action Plan for the implementation of the UN Security Council Resolution 1325, the Ministry of Defence and Serbian Armed Forces enable much greater representation of women in the system (in comparison to the previous period). ${ }^{9}$ While launching competition for admission of civil candidates to the military schools, as well as possibilities of acquiring the status of a professional soldier, there is no discrimination in terms of gender equality. The same conditions are provided for candidates of both gender. However, participation of the female members of the Ministry of Defence and Serbian Armed Forces in multinational operations is not in a direct proportion to representation of women in the system in total (percentage of participation in multinational operations is at much lower level).

\section{Some aspects of media reporting}

Presentation of results of the conducted research has been used to show what media treatment of the Serbian Armed Forces second mission was like from 2010 until 2017 that is how media referred in this period to the abovementioned subject of the research. The 2010 year has been taken as the beginning of analyzed period, having in mind that preconditions for greater participation of the Serbian Armed Forces members in multinational operations were created at that time (the adequate normative-legal regulation was provided, necessary preparations in the system were carried out, etc.). The sample of analyzed media were eight newspapers and four weekly magazines, as well as eight TV

\footnotetext{
${ }^{8}$ Around 4.000 Serbian Armed Forces members have filled in a questionnaire and thus expressed their wish to take part in multinational operations.

${ }^{9}$ According to the statement of Director of the Strategic Research Institute Jovanka Šaranović in the panel discussion "Gender equality and youth", now we have around $20.44 \%$ of women in the system. (Source: RT Vojvodina, $21^{\text {st }}$ November 2017).
} 
and one radio station. ${ }^{10}$ The main criterion when selecting the abovementioned media is based on the continuity of the existence with prior respect for available data on press circulation and ratings of television stations.

Results of the conducted research, in which content analysis was mainly used, have provided answers to several questions: how much publicity in media there was, what the value orientation of analyzed reports was, which journalist forms were mostly used, whether the authors of reports are journalists or news agency, etc. On the basis of the abovementioned, it is possible not only to review the existing situation, but also to consider options for the improvement of the current situation.

This paper shows the results of content analysis of 2.170 reports from the selected sample of printed and electronic media. ${ }^{11}$ At an annual level media which have published 271 reports on average that is 0.74 reports daily have been analyzed. On the basis of indicators of the scope of publicity, a high level of media interest for participation of the Serbian Armed Forces members in multinational operations is evident.

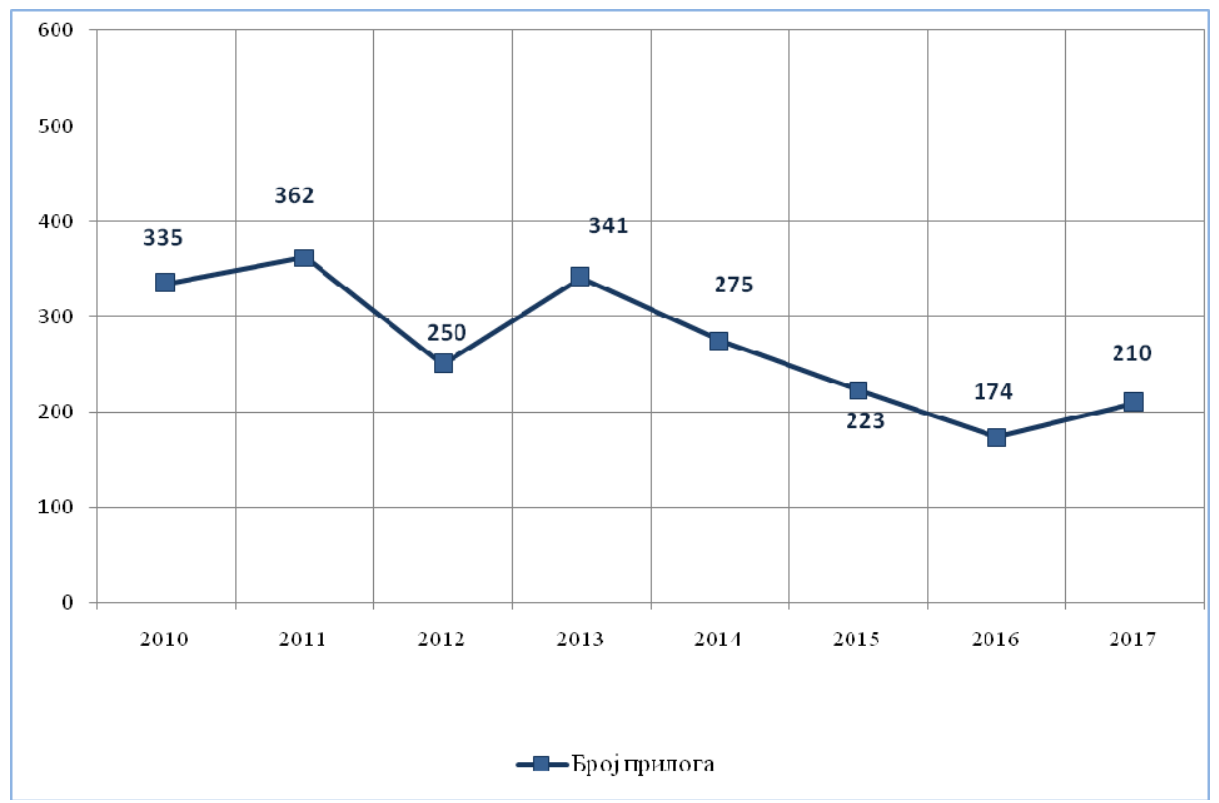

Graph 2 - The number of analyzed reports in the period 2010-2017

At the same time, the difference in the intensity of media reporting is obvious: in the first half of the analyzed period more reports were published on average than in the second part of the period. This result can be explained by the fact that in the first couple of

\footnotetext{
${ }^{10}$ Newspapers: Politika, Večernje novosti, Dnevnik, Blic, Alo, Kurir, Danas and Narodne novine. Weekly magazines: NIN, Vreme, Svedok and Pečat. TV stations: RTS1, RTS2, Pink, RTV, B92 (O2TV), Prva television, Studio B and Happy. Radio station: Radio Belgrade 1.

${ }^{11}$ See Graph 2.
} 
years more massive engagement of the Serbian Armed Forces members outside the country's borders has been a novelty in the engagement of the Armed Forces. On the one hand, it has contributed to the interest of media in this sphere, and on the other hand, there has been the need to inform the public about that mission of the Armed Forces, in which media, of course, have the important role.

Moreover, during the analyzed period in total, the uneven distribution of reports in the press and on TV stations is evident. ${ }^{12}$

In printed media there was twice more reports (180 on average) than on TV stations (91 on average).

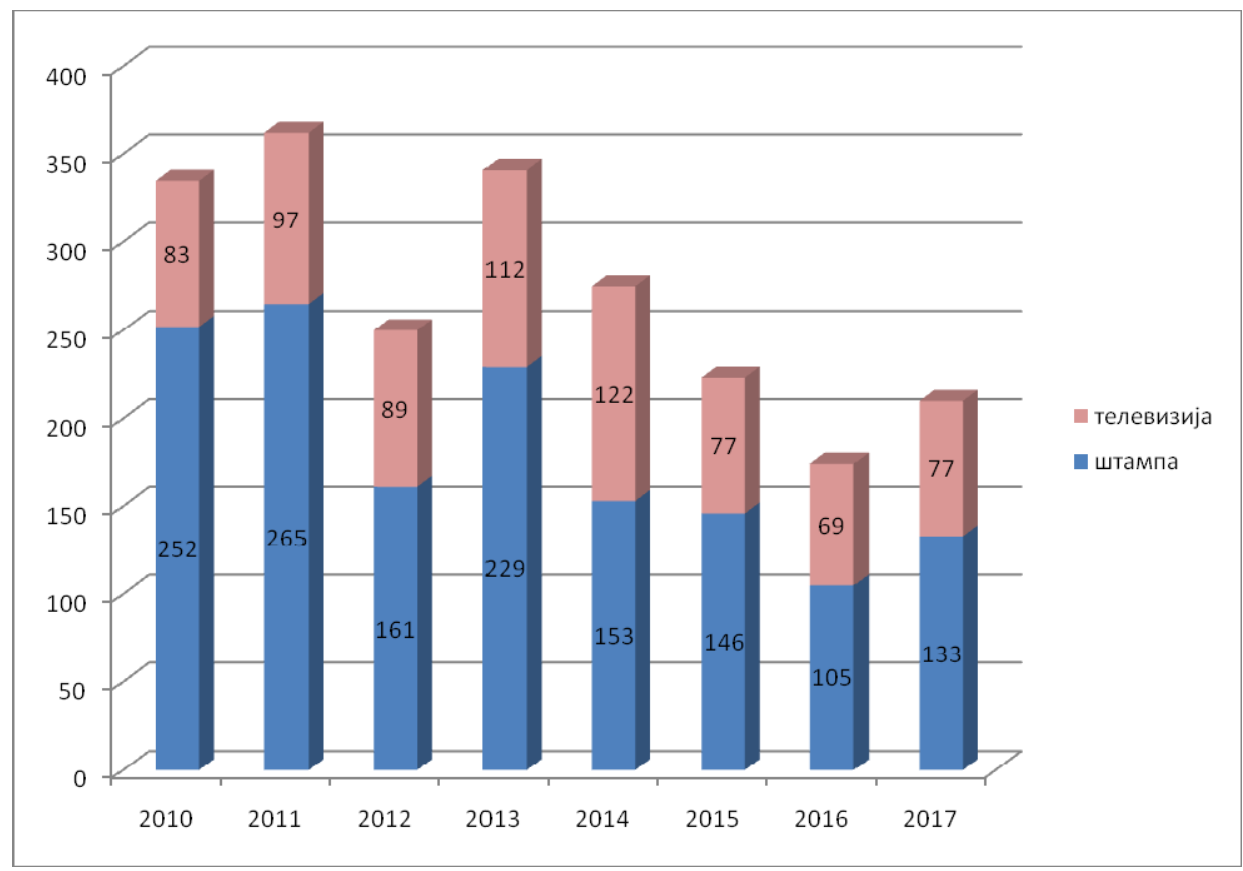

Graph 3 - Comparative review of number of reports in the press and on TV stations

When it comes to orientation of analyzed reports, ${ }^{13}$ during the whole considered period there is distinct domination of reports with neutral value orientation (almost $90 \%$ in the first half). In relation to positively oriented reports it can be noticed that their presence in the second half of the analyzed period is much greater: from the average $9.5 \%$ (in the first half) to the increase to $24 \%$. Negatively oriented reports are constantly at a very low level (from $1 \%$ to $3 \%$ ).

\footnotetext{
${ }^{12}$ See Graph 3.

${ }^{13}$ See Graph 4.
} 


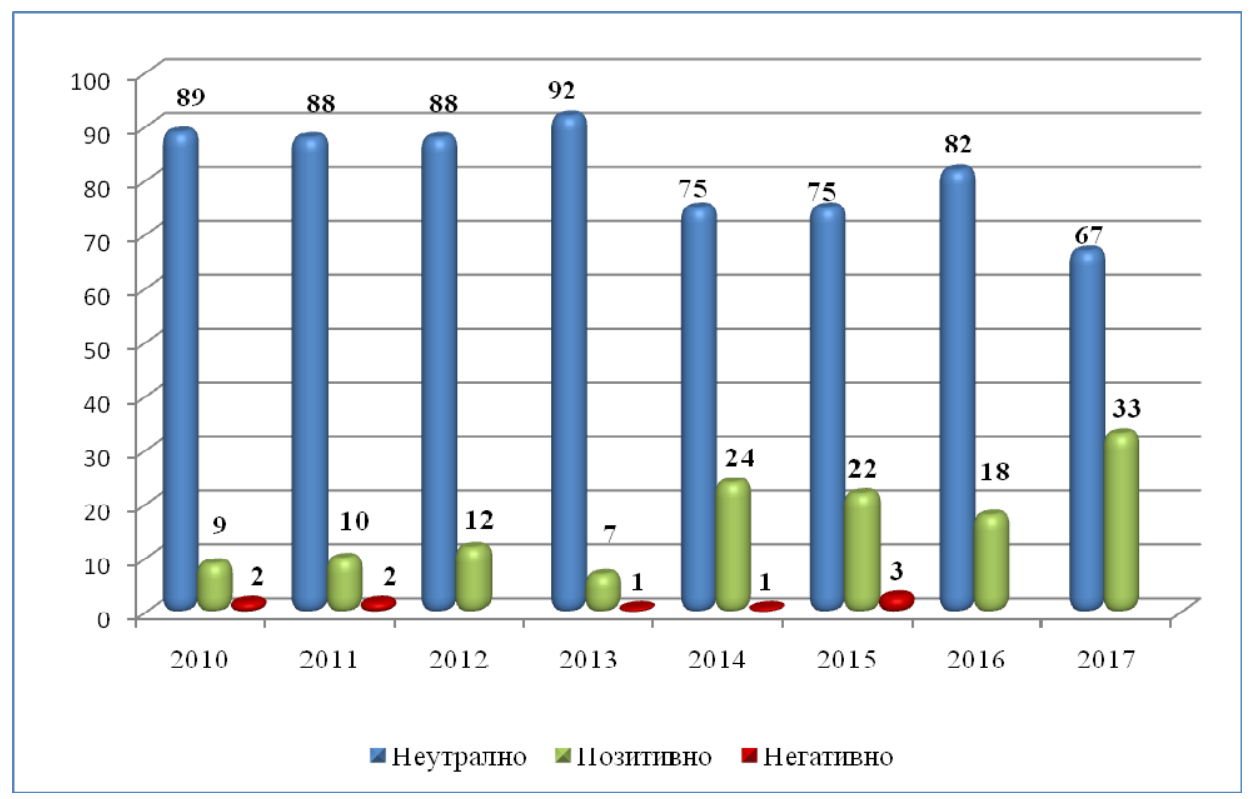

Graph 4 - Orientation of analyzed reports (in percentage)

The belief that execution of the second mission of the Serbian Armed Forces is beneficial to foreign policy position of the country and its citizens has primarily affected the increase of reports with positive connotation in the second half of the considered period. In addition, rotations of the Serbian Armed Forces members in multinational operations became actually the usual activity in the second half of the period, which was mainly conducted without major problems. The similar reasons can also be used to explain rather low percentage of negatively oriented reports.

During the analysis of genre presence in the analyzed reports the following genre classification has been used: informative (news, reports, announcements), interactive (statements, interviews) and interpretative (review, comment, article). The obtained results point at very great presence of informative genre ( $85 \%$ on average), relatively small presence of interactive genre (excluding the first two years) and rather low presence of interpretative genre (in the range $1 \%-5 \%){ }^{14}$

The data that more than $4 / 5$ of the analyzed reports belongs to informative genre highlights the fact that media report on engagement of the Serbian Armed Forces members in multinational operations mainly factually, without assessment, relying primarily on agency news. This mainly means a chronological description of events without placing them in broader context.

\footnotetext{
${ }^{14}$ See Graph 5.
} 


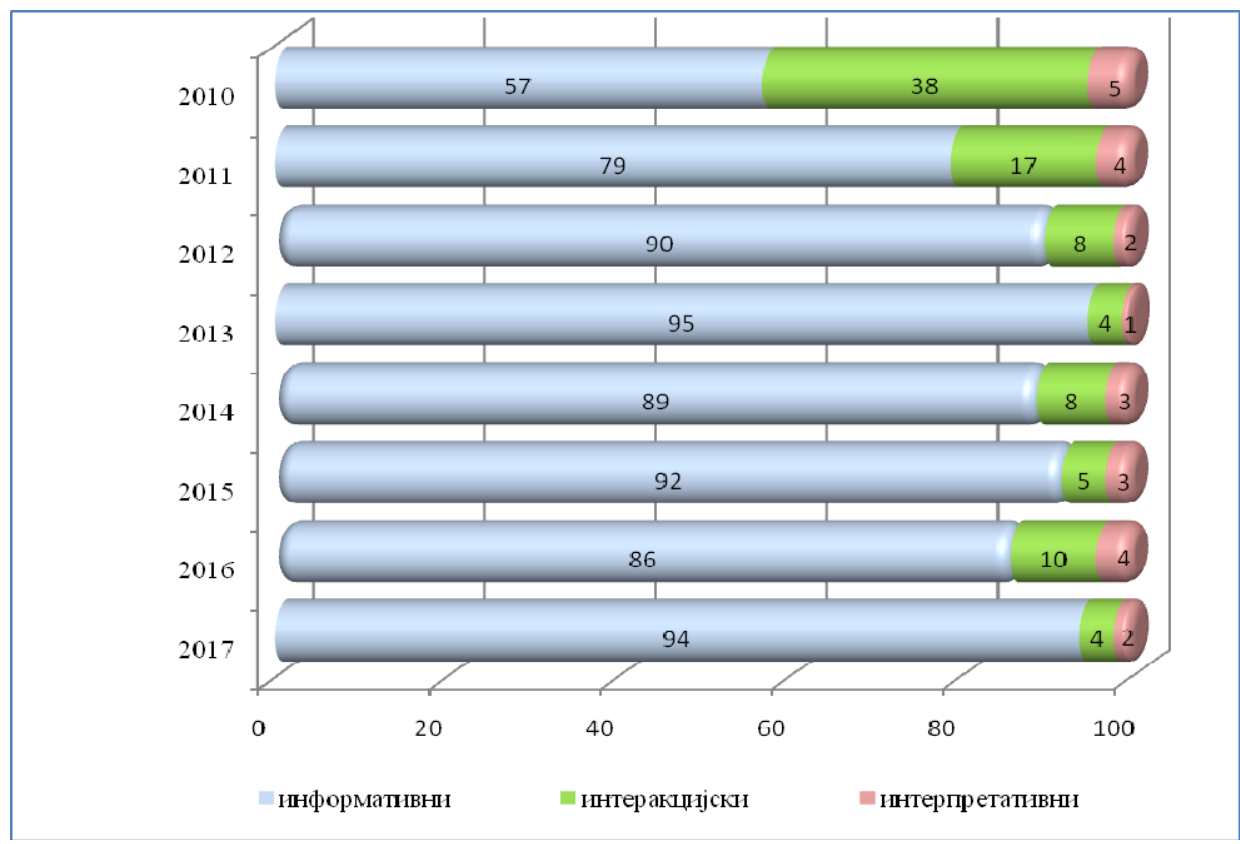

Graph 5 - Genre presence in percentage in the analyzed period

Excluding the first two years, when interactive genre was several times greater than in the later period, its presence is relatively modest $-6.5 \%$. Moreover, during 2010 and 2011, after creating conditions for greater engagement of the Serbian Armed Forces members in execution of the second mission, there was the need to explain additionally the significance of those activities, a manner of their conduct, etc. Suspending the obligation of doing military service and transfer to the concept of the professional army have also given an additional impulse in such direction. After the initial period (in 2010 the share of interactive genre was 38\%, and in $2011-17 \%$ ), its presence decreased rapidly several times and it remained at average $6.5 \%$ until the end of the period.

Genre presence containing analytical elements with the possibility to express an attitude (review, comment, article) is at a rather low level - with slight oscillations during the analyzed period its share is from $1 \%$ to $5 \%$. There are several reasons for such state, and some of them are: 1) general situation in media, which means fast and short information (usually with a statement by an official as a supplement to news), without review, comments, special TV shows as a more complex manner of considering certain issue; 2) media main interest in bad news; 3 ) journalists are often not experts in reporting on the activities of the Ministry of Defence and Serbian Armed Forces, thus basing their reports on agency news. 
The analysis shows that in the first half of the period reports are mostly signed by journalists, and in the second half by news agency. ${ }^{15}$ It is also obvious that the presence of news agency is increased $(76 \%$ in 2017$)$ whereas journalists are more rarely seen as authors of reports $(24 \%$ in 2017). The reasons for such state are mainly mentioned in the previous considerations.

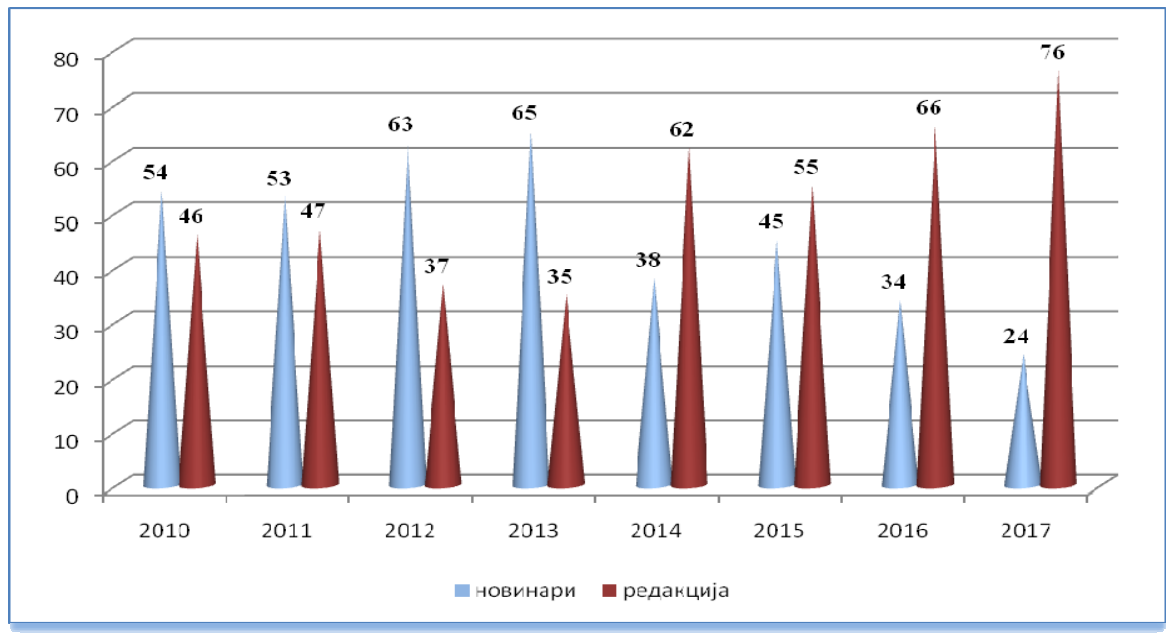

Graph 6 - Authors of analyzed reports - journalists or news agency (in percentage)

\section{Conclusion}

The execution of the second mission of the Serbian Armed Forces in the function of meeting foreign policy objectives is a very important activity, having in mind the fact that the Republic of Serbia affirms cooperative security concept. In such context, guided primarily by its national interests and capacities, our country invests great efforts in order to contribute to keeping peace and stability in the world. During the last couple of years the expansion in this field has been obvious, both in terms of number of the engaged personnel and expansion of engagement framework - taking part in EU multinational operations.

By taking part in UN multinational operations the Serbian Armed Forces members continue the rich tradition based on participation of the Armed Forces of the Socialist Federal Republic of Yugoslavia in traditional peacekeeping missions of the world organization. In the period after the Cold War the international circumstances have, of course, changed, which undoubtedly affected changes in the character of UN peacekeeping missions (from classical monitoring a truce between conflicting parties to peace enforcement). By engagement in the missions established by adequate resolutions of the UN Security Council with clearly defined mission mandate, as well as precisely set tasks of its participants, the Serbian Armed Forces members give a maximum contribution in accordance with their capacities to keeping peace and stability in the world.

\footnotetext{
${ }^{15}$ See Graph 6.
} 
Bearing in mind the fact that the EU membership is one of the priority foreign policy objectives of the Republic of Serbia, in recent years the Ministry of Defence and Serbian Armed Forces members have also participated in EU multinational operations. In order to create preconditions for engagement of the Serbian military representatives in operations and missions under the auspices of the EU, the adequate treaties have been previously signed. Thus, although it has the status of a candidate for admission, and not the EU full member, the Republic of Serbia expresses a commitment to give its contribution to the Common Foreign and Security Policy of the EU.

In relation to the execution of the second mission of the Serbian Armed Forces, the adequate normative-legal framework has been provided. In the period 2002-2009 undertaking activities in the mentioned field encountered numerous challenges including the lack of adequate legal regulation. After passing the set of doctrinal documents and legislation, participation of the Serbian Armed Forces members in UN and EU multinational operations has been regulated in detail. The foundation is provided in the Constitution, the National Security Strategy and the Defence Strategy of the Republic of Serbia that is in provisions of the Law on Defence and the Law on the Serbian Armed Forces, and most details are in the Law on engagement of the Serbian Armed Forces and other defence forces in multinational operations outside the Republic of Serbia borders (it stipulates, inter alia, types of peacekeeping operations in which the Serbian Armed Forces members can participate, then the process of decision-making at the state level in this field, as well as status, rights and obligations of the engaged Serbian Armed Forces members during their participation in missions).

Preconditions for successful execution of the second mission of the Serbian Armed Forces in the system have been created by numerous activities undertaken in different organizational structures of the Ministry of Defence and Serbian Armed Forces that is preconditions for greater participation of their personnel in UN and EU multinational operations have been fulfilled. The special importance among them has the Peacekeeping Operations Centre, which provides for the planned character of engagement of the Serbian Armed Forces members in multinational operations with maximum effort in terms of selection, training level, equipping of candidates and monitoring their engagement in missions. Furthermore, the training system has been modified and adapted to contemporary armies requirements, which enables easier reaching the necessary level of interoperability of potential participants in multinational operations (additional training is organized if necessary). In respect of the fact that foreign languages knowledge (mainly English) is one of important conditions for participation in missions, the Military Academy carries out continuous training of the Serbian Armed Forces members within STANAG programme for successful performance of tasks in multinational operations. Moreover, curricula from the field of social sciences at all levels of professional development of the Serbian Armed Forces members are a solid foundation for understanding events in the international community, considering and defining national interests, as well as importance of participation in multinational operations.

Among contributors (both at the world and European level) the Republic of Serbia takes a relatively high place by participating in six ongoing UN and four EU multinational operations. This is particularly important taking into account its geographical, demographic and economic indicators. The Serbian Armed Forces members have received official recognition several times from the mission management for the expressed professionalism and the 
The second mission of the Serbian Armed Forces - genesis, characteristics and media treatment

high training level in performance of tasks. In addition to praises, recognition has often been manifested by including them into higher levels of mission management.

Results of the mentioned research emphasize that Serbian media follow continuously participation of the Serbian Armed Forces members in UN and EU multinational operations. A relatively high level of media interest in the mentioned field is illustrated by the number of reports in the analyzed period: almost one report daily. However, in the analyzed period there is certain difference in the intensity of media reporting: during the first couple of years there were more reports because the topic was relatively new, and later participation of the Serbian Armed Forces members in multinational operations became an usual activity.

When it comes to orientation of analyzed reports, the situation is very favourable: neutral value orientation dominates with relatively high presence of positively oriented reports and almost negligible share of negative ones. The decisive influence on this is exerted by the belief that it is an usual activity (especially due to professionalization of the Armed Forces), which contributes greatly to achieving foreign policy objectives of the country.

Therefore, on the basis of the presented results of the research it can be concluded that the scope of publicity and value orientation of reports in relation to participation of the Serbian Armed Forces members in multinational operations are very good. However, it cannot be said so for certain characteristics of analyzed reports. The features of an "ordinary text" from the conducted research are: short form, unnoticeable headline, usually without announcement on the front page, often not signed by a journalist but by news agency, and a photograph that illustrates a text, which is a very expressive means, is not used enough.

The analysis of genre presence also brings us to the knowledge that in analyzed reports there is no critical relation to participation of the Serbian Armed Forces members in multinational operations, which could point to potential direction of the current situation enhancement. Besides that, in reviews, comments and articles it is necessary to put a topic that is considered in broader context, which would enable the public to find out something more about a mission the Armed Forces members are sent to (its mandate, experiences of its participants, etc.)

The reports on participation of the Serbian Armed Forces members in UN and EU multinational operations are primarily published in the periods of rotations (going to a mission and returning from it). Statements of officials dominate then and statistical data on number of missions, as well as number of the engaged Armed Forces members. Most media devote very little attention to the main characteristics of those missions - conditions and reasons for their establishment, tasks performed by their participants, the expected benefits for the Republic of Serbia, etc., and there are few reports on life and work of the Serbian Armed Forces members during their engagement in missions.

\section{References}

[1] Абусара, А., „Мировне мисије Уједињених нација - између славне прошлости и несигурне будућности", Безбедност западног Балкана бр.16, Београд, 2010.

[2] Безбедносни и одбрамбени аспекти прикључења Републике Србије Европској унији (група аутора), Институт за стратегијска истраживања, Медија центар „Одбрана”, Београд, 2014.

[3] Бела књига одбране Републике Србије, Медија центар „Одбрана”, Београд, 2010.

[4] Доктрина Војске Србије, Медија центар „Одбрана”, Београд, 2010.

[5] Доктрина операција Војске Србије, Медија центар „Одбрана”, Београд, 2012. 
[6] Дулић, Драгана, Мировне и хуманитарне операције, Службени гласник, Београд, 2008.

[7] Ејдус, Ф., Савковић, М., Драгојловић, Н., Ка борбеној групи Западни Балкан - Визија одбрамбене интеграције Србије у ЕУ 2010-2020, Центар за цивилно-војне односе, Београд, 2010.

[8] Глишић, М., „Војне снаге у мировним операцијама Организације уједињених нација”, Војни гласник 1/2005, Војноиздавачки завод, Београд, 2005.

[9] Изазови спољне политике Србије, (зборник), Фондација Фридрих Еберт, Европски покрет у Србији, Београд, 2015.

[10] Јовић, Ж., Мировне мисије Уједињених нација, савремени изазови, Међународна политика 1149/2013, Београд, 2013.

[11] Кајтез, И., Гостовић, Д., Гроздић, Б., „Потребна знања официра Војске Србије у области друштвено-хуманистичких наука за учешће у међународним мисијама”, Војно дело (јесен 2012), Београд, 2012.

[12] Ковач, М., „Политичка или војна неутралност Републике Србије”, Економија и безбедност, Центар за цивилно-војне односе, Београд, 2009.

[13] Лучић, 3., Допуђа, П., „Нови концепт обуке Војске Србије”, Нови гласник 4/2007, Београд, 2007.

[14] Маркош, М., Учење енглеског језика у контексту припрема припадника Војске Србије за учешће у операцијама подршке миру, Војно дело (пролеће 2011), Београд, 2011.

[15] Матијевић, М., Рабреновић, А., Операције Уједињених нација за изградњу мира и појам одрживог мира, Институт за упоредно право, Београд, 2011.

[16] Милић, Т., Међународно право и учешће припадника Војске Србије у мултинационалним операцијама Европске уније, Војно дело 2/2015, Београд, 2015.

[17] Милошевић, М., „Стидљивим кораком на велику сцену: изазови и препреке учествовања Србије у мултинационалним операцијама”, Безбедност западног Балкана бр. 16, Београд, 2010.

[18] Милутиновић, С., „Конституенси мировних операција Организације уједињених нација друге генерације”, Школа националне одбране, магистарски рад, Београд, 2006.

[19] Младеновић, М., Иваниш, Ж., Роквић, В., Развој институција и изградња политичког система Србије, Факултет безбедности, Београд, 2012.

[20] Радончић, Хајрадин, Војска Србије у мировним операцијама Уједињених нација, Задужбина Андрејевић, Београд, 2008.

[21] Рачић, Обрад, Уједињене нације: између моћи и права, Службени гласник и Факултет политичких наука, 2010.

[22] Савковић, М., „Европска унија као носилац операција подршке миру”, Безбедност западног Балкана бр.16, Београд, 2010.

[23] Симић, Р. Д., Наука о безбедности: савремени приступи безбедности, Службени лист СРЈ и Факултет политичких наука, Београд, 2002.

[24] Стефановић, С., Форца, Б., Предуслови и неопходне мере за ефикасно и ефективно учешће Војске Србије у мисијама и операцијама заједничке безбедносне и одбрамбене политике Европске уније, Војно дело 3/2015, Београд, 2015.

[25] Cтратегија националне безбедности Републике Србије, Медија центар „Одбрана”, Београд, 2009.

[26] Стратегија одбране Републике Србије, Медија центар „Одбрана”,Београд, 2009.

[27] Шарановић, Ј., Килибарда, З., У корак с временом: Министарство одбране и Војска Србије на путу објективизације родне равноправности, Институт за стратегијска истраживања и Медија центар „Одбрана”, Београд, 2011. 
The second mission of the Serbian Armed Forces - genesis, characteristics and media treatment

[28] Устав Републике Србије, Службени гласник 98/2006, Београд, 2006.

[29] Весић, З., Војска Србије у мировним мисијама, Медија центар „Одбрана”, 2010.

[30] Закон о одбрани, Службени гласник 88/2009, Београд, 2009.

[31] Закон о Војсци Србије, Службени гласник 88/2009, Београд, 2009.

[32] Закон о употреби Војске Србије и других снага одбране у мултинационалним операцијама ван граница Републике Србије, Службени гласник Републике Србије бр. 88/09, Београд, 2009.

[33] Жујовић, Д., Мировне мисије Уједињених нација, стручни рад, Факултет политичких наука, Београд, 2008.

[34] www.mod.gov.rs

[35] www.vs.rs

[36] www.un.org

[37] www.eeas.europa.eu 